Each curve defines the variation of TSH and TH with thyroid efficiency at a particular TRH concentration, with limits that correspond to the normal range of FT4 index $(70-140 \mathrm{nmol} / \mathrm{l}$; $54.5-109.0 \mu \mathrm{g} / \mathrm{l})$. The disposition of such curves is highly reminiscent of the dose-response curves obtained with a drug in the presence of varying doses of antagonist, ${ }^{20}$ consistent with the concept that the physiological error signal measured as serum $\mathrm{TSH}$ is the net result of a competitive antagonism between thyroid hormone and TRH at pituitary level. ${ }^{21}$ The existence of such curves would provide a plausible explanation for high TSH concentrations in otherwise euthyroid people whose FTC was reduced through any cause. Furthermore, they question the validity of a rise in TSH concentration above the reference range as a strict criterion of hypothyroidism unless it is contended that very minor deviations from optimum serum T4 require replacement therapy. Thyroid failure might then be logically defined as the point at which thyroid function becomes saturated. This is the point beyond which the fall in TH would be expected to accelerate and is analogous to the definition of organ failure applied to other body control systems-for example, cardiac and respiratory.

In any event the TSH concentration, being a directly measurable function of the error signal, appears to be the most sensitive index of thyroid state currently available, and loop gain the factor that links the two.

We acknowledge the co-operation of Drs A M M Shepherd and $\mathrm{J} \mathrm{J}$ Manns in providing access to their data on a hypothyroid patient receiving T4-replacement therapy, and thank Drs D S Hewick and G J Naylor for data on lithium-treated patients, Drs P S Brown (department of pharmacology, Bristol University) and $\mathbf{R}$ Brown (department of mathematics, Dundee University), for advice, and Mrs Joyce Simpson and Dr Elizabeth Hunter for laboratory help.
This work was supported by a Scottish Hospital Endowments Research Trust grant to JSB.

Requests for reprints should be addressed to: $\mathrm{Dr} \mathrm{T} J$ Wilkin, Department of Therapeutics, Ninewells Hospital, Dundee DD2 $1 \mathrm{UB}$.

\section{References}

1 Gordin, A, et al, Acta Endocrinologica, 1974, 75, 274.

2 Vanhaelst, L, and Bastenie, P A, Nouvelle Presse Médicale, 1975, 4, 1813.

3 Toft, A D, et al, Lancet, 1973, 2, 644.

4 Tunbridge, W M G, Harsoulis, P, and Goulden, A W G, British Medical fournal, 1974, 2, 89.

${ }^{5}$ Hedley, A J, et al, Lancet, 1971, 1, 155.

${ }^{6}$ Evered, D, et al, British Medical fournal, 1975, 1, 25.

7 Evered, D, et al, British Medical fournal, 1973, 1, 657.

${ }^{8}$ Himsworth, R L, and Fraser, P M, British Medical fournal, 1973, 2, 295.

๑ Henneman, G, et al, British Medical fournal, 1975, 4, 129.

10 Billiewicz, W Z, et al, Quarterly fournal of Medicine, 1969, 38, 255.

11 Villeneuve, A, et al, International fournal of Clinical Pharmacology, 1974, 1,75 .

12 Hall, R, Amos, J, and Ormston, B J, British Medical fournal, 1971, 1, 582.

${ }^{13}$ Seth, J, Toft, A D, and Irvine, W J, Clinica Chimica Acta, 1976, 68, 291.

14 Wilcoxon, F, Biometrics Bulletin, 1945, 1, 80.

15 Hoskins, R G, fournal of Clinical Endocrinology, 1949, 9, 1429.

16 Reichlin, S, et al, Recent Progress in Hormone Research, 1972, 28, 229.

17 Jeffries, W McK, et al, fournal of Clinical Endocrinology, 1956, 16, 1438.

18 Slingerland, D W, fournal of Clinical Endocrinology, 1972, 35, 912.

19 Dransfield, P, Engineering Systems and Automatic Control. Englewood Cliffs, NJ, Prentice-Hall, 1968.

20 Goldstein, A, Aronow, L, and Kalman, S M, Principles of Drug Action, 2nd edn, p 89. New York, Wiley, 1974.

21 Vale, W, Burgus, R, and Guillemin, R, Proceedings of the Society of Experimental Biology and Medicine, 1967, 125, 210.

(Accepted 15 February 1977)

\title{
Plasma immunoreactive corticotrophin and lipotrophin in Cushing's syndrome and Addison's disease
}

\author{
J J H GILKES, LESLEY H REES, G M BESSER
}

British Medical fournal, 1977, 1, 996-998

\section{Summary}

Plasma immunoreactive corticotrophin (ACTH) and lipotrophin (LPH) were measured in patients with raised circulating concentrations from a pituitary or an ectopic source. They were measured again in seven patients after they had received hydrocortisone. Plasma ACTH concentrations were higher than LPH concentrations in patients with a pituitary source of their homones, whereas this relation was reversed when the source was ectopic. After hydrocortisone administration the half

\footnotetext{
Department of Dermatology, University College Hospital and University College Hospital Medical School, London WC1

J J H GILKES, MD, MRCP, consultant dermatologist

St Bartholomew's Hospital, London EC1

LESLEY H REES, MD, MRCP, senior lecturer, department of chemical pathology

G M BESSER, MD, FRCP, professor of endocrinology
}

\begin{abstract}
life of immunoreactive ACTH was 40 minutes and that of LPH 95 minutes, resulting in a reversal of the normal relation of ACTH to LPH. The use of two antisera with different specificities for measuring LPH has further shown that pituitary LPH differs from ectopic LPH. Relatively less $\gamma$-LPH than $\beta$-LPH was produced from ectopic sources, the relation being reversed in patients with a pituitary source for their raised concentrations.

Measuring plasma LPH as well as ACTH might therefore help in deciding whether a patient with Cushing's syndrome has a pituitary or ectopic source of ACTH, which sometimes presents a difficult clinical problem.
\end{abstract}

\section{Introduction}

Abe et $a l^{1}$ showed a close relation between plasma immunoreactive corticotrophin $(\mathrm{ACTH})$ and $\beta$-melanocyte-stimulating hormone $(\beta-\mathrm{MSH})$ concentrations in patients with increased secretion from a pituitary or ectopic source. Since then, however, the molecule of small molecular weight that has been identified as human $\beta-\mathrm{MSH}$ has been shown to be a breakdown product derived during in-vitro extraction from larger molecules$\beta$ - and $\gamma$-lipotrophin $(\mathrm{LPH}) .{ }^{2}$ There is no evidence that $\beta$-MSH 
is present either in the human pituitary or plasma but the peptide sequence referred to as $\beta-\mathrm{MSH}$ is contained within naturally occurring $\beta$ - and $\gamma$-LPH..$^{2}$ Antisera previously thought to react with the synthetic peptide $\beta-\mathrm{MSH}$ and to measure the endogenous hormone appear in fact to cross-react with and measure $\beta$ - and $\gamma-\mathrm{LPH} .{ }^{4}$ Since $\beta-\mathrm{LPH}$ contains 91 and $\gamma-\mathrm{LPH}$ 58 amino-acids, however, different antisera that react equally with synthetic $\beta$-MSH may react differently with the LPH molecules. We investigated whether this pattern of crossreactions varies in different states of ACTH-LPH secretion in patients with non-endocrine tumours and those with pituitarydependent Cushing's disease or Nelson's syndrome (postadrenalectomy hyperpigmentation in Cushing's disease). We also studied the effect of giving hydrocortisone to patients with raised ACTH-LPH secretion.

Until recently dissociation of plasma ACTH and LPH concentrations has not been shown in any physiological or pathological condition. ${ }^{5}$ Here we examine more closely the relation of these two peptides and show the added value of their simultaneous measurement.

\section{Patients and methods}

We used two antisera in the LPH radioimmunoassay. On a molar basis one antiserum (B7) reacted equally with purified $\beta_{\mathrm{h}}$ - and $\gamma_{\mathrm{h}}-\mathrm{LPH}$ (Lowry); the other (NZ) reacted with $\gamma_{h}-\mathrm{LPH}$ but only $3 \%$ with $\beta_{h}-\mathrm{LPH}$. Both antisera reacted fully with synthetic $\beta_{\mathrm{h}}-\mathrm{MSH}{ }^{4}$ The assay sensitivity with the B7 antisera was $10 \mathrm{ng} / 1$ and with the NZ antisera $15 \mathrm{ng} / 1$ (3-5 $\mathrm{ml}$ of plasma extracted throughout). Plasma ACTH was measured with an $\mathrm{N}$-terminal radioimmunoassay, ${ }^{6}$ which had a sensitivity of $10 \mathrm{ng} / \mathrm{l}$. Synthetic $\beta_{\mathrm{h}}-\mathrm{MSH}$ and purified native human ACTH (Lowry) were used as standards and tracer. The plasma levels of immunoreactive peptides were expressed in mass concentration and referred to as ng/l B7-LPH, NZ-LPH, or ACTH.

Blood samples were collected from 23 normal laboratory workers at 9 am and $9 \mathrm{pm}$. Basal samples were also taken from 12 patients with proved Cushing's disease, eight with Nelson's syndrome, nine with Addison's disease, and 14 with the ectopic ACTH syndrome. Seven of the patients with raised plasma concentrations of immunoreactive LPH and ACTH from a pituitary source were given hydrocortisone (100 mg intravenously), and samples were collected at $0,30,60,90$, and 120 minutes.

\section{Results}

$B 7-L P H-I n$ all groups of patients plasma B7-LPH concentrations were closely correlated with plasma ACTH concentrations in the

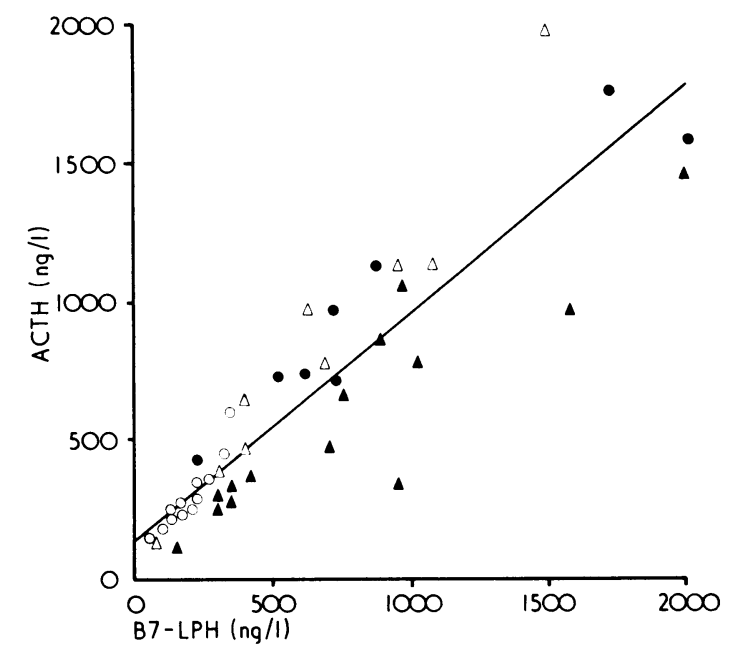

FIG 1-Correlation between plasma ACTH and B7-LPH levels in patients with Cushing's disease (O), Nelson's syndrome $(\Theta)$, Addison's disease $(\triangle)$, and ectopic ACTH syndrome $(\boldsymbol{\Delta}) .(\mathrm{r}=0.88 ; \mathrm{P}<0.001$. $)$

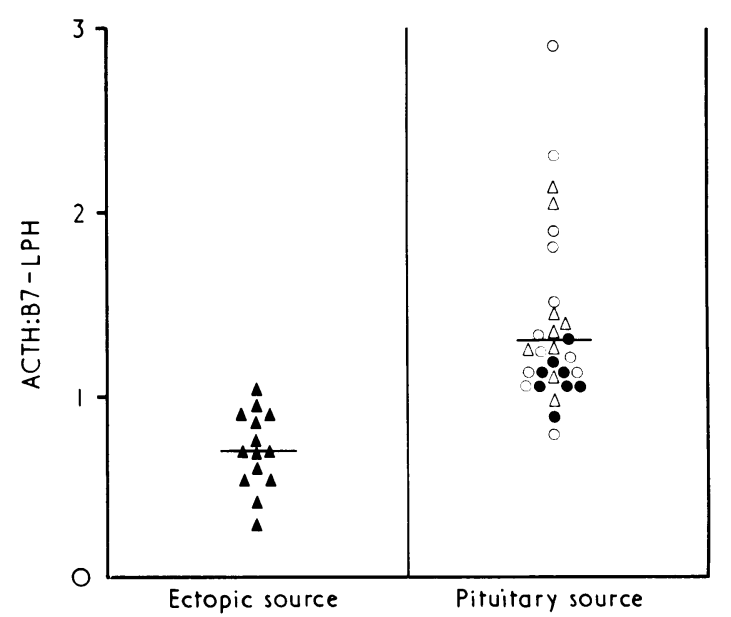

FIG 2-Ratios of ACTH and B7-LPH plasma levels in patients with increased production due to Cushing's disease $(O)$, Nelson's syndrome (O), Addison's disease $(\triangle)$, and the ectopic ACTH syndrome $(\mathbf{\Delta})$. Horizontal bars represent mean ratios.

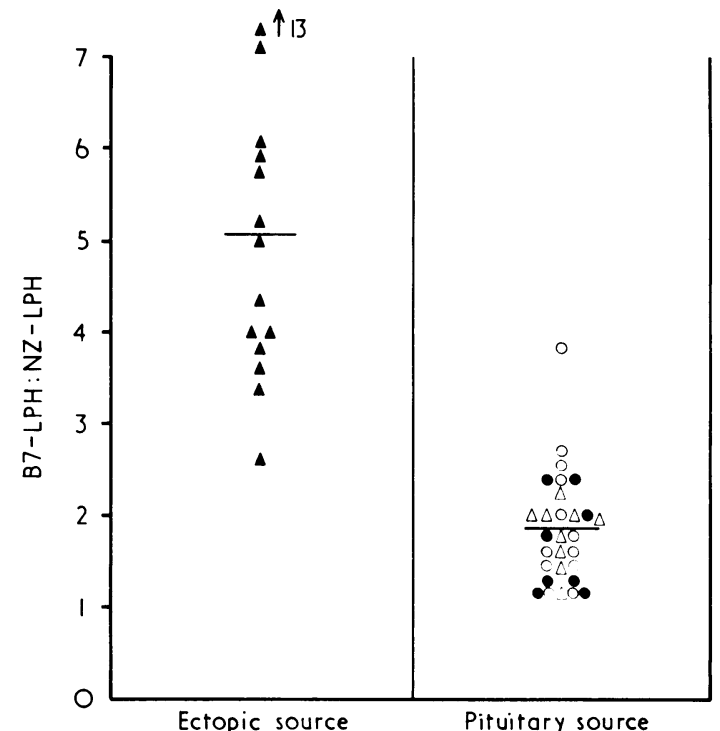

FIG 3-Ratios of B7-LPH and NZ-LPH plasma levels in patients with increased circulating levels due to Cushing's disease (O), Nelson's syndrome (O), Addison's disease $(\triangle)$, and the ectopic ACTH syndrome $(\boldsymbol{\Delta})$. Horizontal bars represent mean ratios.

same blood sample (fig 1) $(P<0 \cdot 001)$. In each normal subject ACTH concentrations were higher than the B7-LPH levels, the mean ratio being $1 \cdot 6$. In 26 of the 29 patients with a pituitary source of ACTH excess ACTH concentrations were equal to or higher than B7-LPH levels (mean ratio $1 \cdot 3$, range $0 \cdot 7-2 \cdot 9$ ). In contrast, 13 of those with an ectopic source of ACTH excess had levels that were lower than B7LPH levels (mean ratio $0 \cdot 7$; range $0 \cdot 3-1 \cdot 1$ ) (fig 2).

$N Z-L P H$-In normal subjects and in all groups of patients plasma concentrations of NZ-LPH were closely correlated with plasma ACTH $(r=0.8 ; P<0.001)$. In the normal subjects and those patients with a pituitary source of ACTH excess ACTH concentrations were higher in all subjects (mean ratio $2 \cdot 2$; range $1 \cdot 1-5 \cdot 2$ ). If the ACTH-LPH excess was from an ectopic source ACTH levels were again higher in every patient (mean ratio $3 \cdot 7$; range $2 \cdot 0-7 \cdot 6$ ).

In all patients with an ectopic source of ACTH-LPH excess B7-LPH concentrations were higher than NZ-LPH levels, the mean ratio of B7-LPH:NZ-LPH being 5.1 (range 2.5-13.0), while in normal subjects and those with a pituitary source of ACTH-LPH excess the discrepancy was much less, the mean ratio of B7-LPH:NZ-LPH being $1 \cdot 8$ (range $1 \cdot 1-3 \cdot 8$ ) (fig 3 ).

After hydrocortisone had been given to patients with an increased 
pituitary source of ACTH and LPH concentrations of both peptides fell. The half time for the disappearance of ACTH was 40 minutes while, in contrast, B7-LPH and NZ-LPH had half lives of about 95 minutes. During hydrocortisone administration, therefore, there was an increasing dissociation between plasma ACTH and LPH.

\section{Discussion}

In normal subjects and in patients with excess ACTH-LPH production from a pituitary source ACTH plasma concentrations were equal to or higher than B7-LPH levels. The reversed relation between circulating plasma B7-LPH and ACTH concentrations in the ectopic ACTH-LPH syndrome might be due to differences in metabolic clearance rates between LPH and ACTH or even to circulating LPH precursors, which may be released because of abnormal hormone packaging within neoplastic tissue. ' Alternatively, the production of a large molecular weight ACTH precursor such as "big ACTH" might be responsible since it may not be fully immunoreactive and it is synthesised by some ectopic ACTH-secreting tumours. ${ }^{8}$

Since the NZ antiserum we used effectively measured only $\gamma-\mathrm{LPH}$, the concentrations of NZ-LPH found were lower than those of B7-LPH in patients with the ectopic ACTH-LPH syndrome. Lower $\gamma$-LPH than $\beta$-LPH may be characteristic of this condition, whereas a relatively higher proportion of $\gamma$-LPH seems to occur in the plasma of these patients with a pituitary source of ACTH and LPH. This may explain the findings of Shapiro et al, ${ }^{9}$ who showed, using chromatography, that ectopic
" $\beta-M S H$ " and pituitary " $\beta-M S H$ " were of different molecular weights. These differences between circulating LPH immunoreactivities, as well as their relation to ACTH concentrations, might be of value in deciding whether a patient with Cushing's syndrome has a pituitary or ectopic source of ACTH-a clinical problem which may present considerable diagnostic difficulty. The well-known dissociation between ACTH and " $\beta-M S H$ " in renal failure ${ }^{5}$ would not in practice be a problem, since plasma " $\beta-M S H$ " concentrations do not rise significantly until renal function is grossly impaired.

These studies were supported by a grant from the Cancer Research Campaign and the Joint Research Board of St Bartholomew's Hospital. We are grateful to Dr R A Donald for the gift of the NZ antiserum.

\section{References}

1 Abe, K, et al, fournal of Clinical Investigation, 1969, 48, 1580.

2 Scott, A P, and Lowry, P J, Biochemical fournal, 1974, 139, 593.

${ }^{3}$ Bloomfield, G A, et al, Nature, 1974, 252, 492.

${ }^{4}$ Gilkes, J J H, et al, fournal of Clinical Endocrinology and Metabolism, 1975, 40, 450.

${ }^{5}$ Gilkes, J J H, et al, British Medical fournal, 1975, 1, 656.

${ }^{6}$ Rees, L H, et al, Endocrinology, 1971, 89, 254.

${ }^{7}$ Rees, L H, Fournal of Endocrinology, 1975, 67, 143.

${ }^{8}$ Gewirtz, G, and Yalow, R S, fournal of Clinical Investigation, 1974, 53, 1022.

- Shapiro, M, et al, Fournal of Clinical Endocrinology and Metabolism, 1971, 33, 377 .

(Accepted 11 February 1977)

\title{
Inactivation of penicillin by purulent exudates
}

\author{
JOHN DE LOUVOIS, ROSALINDE HURLEY
}

British Medical fournal, 1977, 1, 998-1000

\begin{abstract}
Summary
Four of 22 specimens of human pus inactivated up to $90 \%$ of added penicillin within one hour in vitro. Ampicillin and cephaloridine were also inactivated, but streptomycin and fusidic acid were not. The effect was not related to the protein content of the pus, nor to its $\mathrm{pH}$ value. Microbes that may produce $\beta$-lactamase in small quantities were isolated from three of the four specimens, but the enzyme was not detected in the pus by physical methods nor by microbiological inhibition assay. The inactivating effect was shown to be a property of the solid portion of the pus, and was absent from the filtrate. We suggest that the effect may be an intrinsic property of the host, which should be investigated further as it has important implications for clinical practice.
\end{abstract}

\section{Introduction}

The tissues of some mammals contain enzymes capable of inactivating benzylpenicillin or its esters. Koch et al ${ }^{1}$ reported

\footnotetext{
Queen Charlotte's Maternity Hospital and the Institute of Obstetrics and Gynaecology, London W6 OXG

JOHN DE LOUVOIS, MSC, principal microbiologist

ROSALINDE HURLEY, MD, professor of microbiology
}

that rat brain contained a penicillinase that could destroy benzylpenicillin, and Snow ${ }^{2}$ showed an ester-specific $\beta$-lactamase in liver extracts from six species of mammals, excluding man, which converted the methyl ester of benzylpenicillin to the 3methyl ester of benzylpenicilloic acid. Esterase activity has been shown in the serum of rabbits, ${ }^{2}$ guinea pigs, mice, and rats. ${ }^{3} \mathrm{~A}$ $\beta$-lactamase-like enzyme has been found in the kidneys of albino mice. ${ }^{4}$ Neither $\beta$-lactamase nor any enzyme capable of hydrolysing simple penicillin esters has been shown in man. ${ }^{5}$

We report findings made in the course of establishing methods for assay of antibiotics in pus under conditions of transport $\left(4^{\circ} \mathrm{C}\right)$ or storage $\left(-20^{\circ} \mathrm{C}\right)$. The investigations were carried out on 22 samples of human pus, four of which were found to have a high level of activity against penicillin, ampicillin, and cephaloridine.

\section{Materials and methods}

Pus from 22 patients was examined. Sixteen patients had abscesses of the central nervous system and six had other purulent lesions. Measured quantities of antibiotics were added to pus, and assayed.

Test 1 -One $\mathrm{ml}$ saline containing $30 \mathrm{\mu g}$ penicillin was mixed with 4-ml aliquots of pus and of serum, the latter used as a control. After mixing at room temperature the samples were stored at $4^{\circ} \mathrm{C}$ for one hour, and after addition of equal parts of saline were assayed against penicillin standards in $50 \%$ horse serum using direct sensitivity test (DST) agar (Oxoid) at $\mathrm{pH} 7 \cdot 2$. The final concentration of penicillin in pus and in serum was thus $3.0 \mathrm{mg} / \mathrm{l}$.

Test 2-Penicillin, ampicillin, cephaloridine, streptomycin, and fusidic acid were each added to pus and to serum, so that the final concentrations before assay were $5.0,5.0,5.0,7.5$, and $1.0 \mathrm{mg} / \mathrm{l}$ respectively. The samples were divided; one set was assayed two 